\title{
PENERAPAN MODEL PROBLEM BASED LEARNING (PBL) DALAM MENINGKATKAN HASIL BELAJAR IPS GEOGRAFI SISWA KELAS VIII MTS AR-RIDHA PAISUMBAOS HALMAHERA-SELATAN
}

\author{
Kusrini $^{1}$, Fahran Mustafa ${ }^{2}$ \\ ${ }^{1}$ Dosen Program Studi Pendidikan Geografi, FKIP Unkhair \\ ${ }^{2}$ Mahasiswa Program Studi Pendidikan Geografi, FKIP Unkhair
}

Email: Kusrini@gmail.com

$\begin{array}{ll}\text { Diterima } & : 08-09-2019 \\ \text { Direvisi } & : 15-10-2019 \\ \text { Dipublikasi } & : 04-11-2019\end{array}$

\begin{abstract}
Abstrak. Model problem based learning (PBL) adalah model pembelajaran yang memberi pengertian lebih mendalam serta menekankan pada pengembangan penalaran dan ketrampilan berpikir tingkat tinggi yang ditunjukkan dengan mendorong siswa untuk mempergunakan analisis kritis dalam pemecahan masalah. Penelitian ini dilakukan dengan tujuan untuk meningkatkan hasil belajar siswa pada kelas VIII MTs Ar-Ridha Paisumbaos Halmahera Selatan dengan penerapan pembelajaran melalui model Problem Based Learning (PBL). Desain penilitian adalah penilitian tindakan kelas dengan instrument yang digunakan adalah soal tes, lembar observasi guru dan siswa. Berdasarkan hasil penelitian menunjukan bahwa, dengan menerapkan model pembelajaran Problem Based Learning dapat meningkatkan hasil belajar siswa. Hal ini dapat ditunjukkan dengan perolehan rata-rata skor hasil belajar siswa sebesar 20\% (siklus I) meningkat menjadi 80\% (siklus II). Selain itu, aktivitas belajar siswa meningkat yang ditunjukkan dengan perolehan rata-rata skor aktivitas siswa sebesar $70 \%$ (siklus I) meningkat menjadi $100 \%$ (siklus II). Penerapan pembelajaran model Problem Based Learning (PBL), juga dapat meningkatkan ketuntasan hasil belajar siswa, yaitu jumlah siswa yang tuntas belajar pada siklus I adalah 8 siswa $(58,33 \%)$ meningkat menjadi 25 siswa $(95 \%)$ pada siklus II dari jumlah siswa 25 orang. Selain itu, aktivitas proses belajar mengajar guru meningkat yang ditunjukkan dengan perolehan rata-rata skor aktivitas proses belajar mengajar guru sebesar 70\% (siklus I) meningkat menjadi 100\% (siklus II).
\end{abstract}

Kata Kunci: Model pembelajaran PBL, hasil belajar, IPS geografi

\section{PENDAHULUAN}

Pendidikan merupakan suatu proses tindakan atau perbuatan mendidik, aktivitas dalam mendidik yang merupakan suatu pekerjaan memiliki tujuan yang dicapai dalam pekerjaan tersebut (Nengah, N. M. J. dkk, 2015). Menurut Undang-Undang RI Nomor 20 tahun 2003 tentang sistem pendidikan Nasional pasal (1): pendidikan adalah usaha sadar dan terencana untuk mewujudkan suasana belajar dan proses pembelajaran agar peserta didik secara aktif mengembangkan potensi dirinya untuk memeliki kekuatan spiritual keagamaan, pengendalian diri, kepribadian, kecerdasan, akhlak mulia, serta keterampilan yang diperlukan dirinya, masyarakat, bangsa dan negara.

Tercapai tidaknya tujuan pembelajaran dapat dilihat dari hasil belajar siswa. Salah satu faktor yang mempengaruhi hasil belajar siswa adalah penggunaan model pembelajaran oleh guru (Gulo, 2002). Model pembelajaran efektif dapat digunakan guru untuk mentransfer ilmu dengan baik dan lancar, secara langsung maupun tidak langsung dan model pembelajaran akan efisien jika menghasilkan kemampuan siswa seperti dalam tujuan dan sesuai dengan target materi dan waktu. Salah satu metode pembelajaran yang berorientasi pada siswa dan dapat menimbulkan peran aktif siswa yaitu model problem based learning (PBL) (Turyanto, 2007).

Model PBL (problem based learning) adalah model pembelajaran yang memberi pengertian lebih mendalam serta menekankan pada pengembangan penalaran dan ketrampilan berpikir tingkat tinggi yang ditunjukkan dengan mendorong siswa untuk mempergunakan analisis kritis dalam pemecahan 
masalah (Trianto, 2007). Dengan model PBL, diharapkan dapat membantu siswa mengembangkan diri secara optimal dalam meningkatkan pengetahuan ling kungan hidup.

Menurut Sutrisno (2006), bahwa problem based learning (PBL) diterapkan untuk melatih siswa menjadi efektif dalam menggunakan informasi untuk memecahkan masalah daripada menjadi ensiklopedi berjalan. Model problem based learning (PBL) adalah suatu komponen untuk pengembangan kurikulum dan sistem penyampaian yang mengakui kebutuhan untuk mengembangkan keterampilan pemecahan masalah serta membantu siswa untuk memperoleh pengetahuan dan keterampilan yang diperlukan.

Salah satu prinsip yang penting dalam pendidikan saat ini adalah pembelajaran yang melibatkan siswa secara aktif sehingga proses pembelajaran tidak berpusat lagi kepada guru. Tetapi pada kenyataannya saat ini masih banyak proses pembelajaran yang berpusat pada guru. Siswa hanya menerima apa yang disampaikan guru tetapi tidak benar-benar memahaminya. Hal tersebut disebabkan oleh kegiatan belajar mengajar yang masih kurang efektif yang dilaksanakan oleh guru.

Kebanyakan siswa belum sadar atas pentingnya belajar itu sendiri. Sebagian siswa memiliki motivasi belajar dikarenakan adanya dukungan dari keluarga tetapi motivasi dari diri sendiri kebanyakan siswa belum memilikinya. Hal tersebut berdampak pada hasil belajar siswa. Selama pembelajaran masih banyak siswa yang ramai dan tidak mendengar penjelasan guru. Para siswa juga banyak yang bermalas-malasan dan suka berkeliaran di dalam kelas VIII MTs Ar-Ridha pada saat proses belajar mengajar dimulai.

Berdasarkan keadaan tersebut, diperlukan suatu tindakan yang dapat meningkatkan motivasi dan hasil belajar siswa. Salah satu model pembelajaran yang dapat digunakan adalah Problem Based Learning yaitu pembelajaran berbasis masalah. Melalui proses pemecahan masalah dalam proses pembelajaran, siswa dapat menemukan konsep-konsep dan prinsip-prinsip dalam berbagai pengalaman belajar sehingga membuat siswa menjadi lebih termotivasi yaitu menjadi lebih aktif, kritis kreatif dalam mengikuti pembelajaran.

\section{METODE PENELITIAN}

Penelitian ini dilaksanakan dengan menggunakan desain penelitian tindakan kelas yang terdiri dari beberapa siklus dan tiap siklus terdiri dari tahapan-tahapan sebagai berikut: (1) perencanaan (planning), (2) pelaksanaan tindakan (action), (3) pengamatan (observation), (4) refleksi (reflectsion). Tempat penelitian ini dilaksanakan di MTs Ar-Ridha Paisumbaos Kabupaten Halmahera Selatan, pada semester genap tahun ajaran 2018/2019.

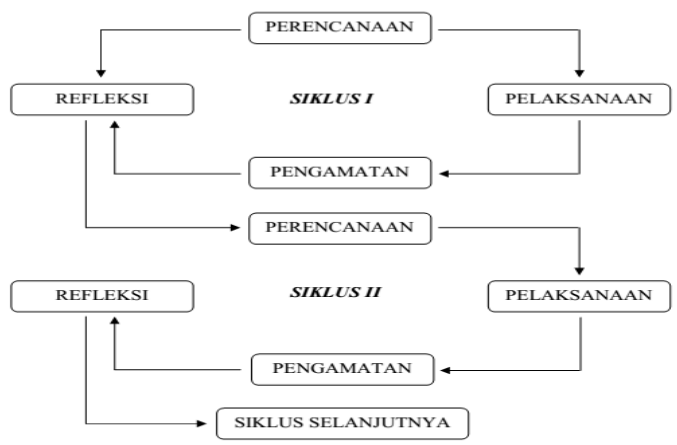

Gambar 1. Bagan Alir PTK (Suharsimi dkk, 2008)

Subyek penelitian adalah siswa-siswi Kelas VIII MTs, mata pelajaran Geografi pada pokok bahasan jenis-jenis tanah dan klasifikasi tanah. Data yang diperlukan dalam penelitian ini diperoleh melalui observasi pengolahan model pembelajaran berbasis masalah, Tes formatif. Tes dilakukan dengan tujuan untuk mengetahui hasil belajar siswa atas materi yang sudah diajarkan. 
Untuk mengalisis data tingkat keberhasilan atau persentase keberhasilan siswa setelah proses belajar mengajar setiap putarannya dilakukan dengan cara memberikan evaluasi berupa soal tes tertulis pada setiap akhir putaran. Analisis dihitung dengan menggunakan statistik sederhana sebagai berikut.

1. Untuk menilai ulangan atau tes formatif

Peneliti melakukan penjumlahan nilai yang diperoleh siswa, yang selanjutnya dibagi dengan jumlah siswa yang ada di kelas tersebut sehingga diperoleh rata-rata.

Tes formatif dapat dirumuskan:

$\mathrm{X}=\frac{\sum \mathrm{X}}{\sum \mathrm{N}}$

Keterangan: $\quad X \quad=$ Nilai rata-rata

$\Sigma \mathrm{X} \quad=$ Jumlah semua nilai siswa

$\Sigma \mathrm{N} \quad=$ Jumlah siswa

2. Untuk ketuntasan belajar

Ada dua kategori ketuntasan belajar yaitu secara perorangan dan secara klasikal. Untuk menghitung persentase ketuntasan belajar digunakan rumus sebagai berikut:

$\mathrm{P}=\frac{\sum \text { Siswa yang tuntas belajar }}{\sum \text { Total siswa }} \times 100$

Kriteria penskoran nilai hasil belajar siswa adalah sebagai berikut:

$0 \%-40 \%=$ kurang baik $\quad 75 \%-80 \% \quad=$ baik

$46 \%-60 \%=$ cukup baik $\quad 81 \%-100 \% \quad=$ sangat baik

\section{INDIKATOR KEBERHASILAN}

Penelitian ini dikatakan berhasil apabila nilai rata-rata hasil belajar siswa $\geq 71$ dan ketuntasan belajar klasikal siswa 75. Adapun kriteria ketuntasan minimal (KKM) dalam proses belajar mengajar yaitu siswa dituntut untuk memenuhi ketuntasan belajar yang ditetapkan oleh pihak sekolah. Ketuntasan yang dimaksud adalah jika siswa dikatakan tuntas, maka nilai yang diperoleh siswa yaitu $\geq 71$.

\section{HASIL DAN PEMBAHASAN}

\section{Hasil Belajar Siswa Pada siklus I dan II}

Data hasil belajar siswa pada siklus satu I dan II pada gambar berikut.

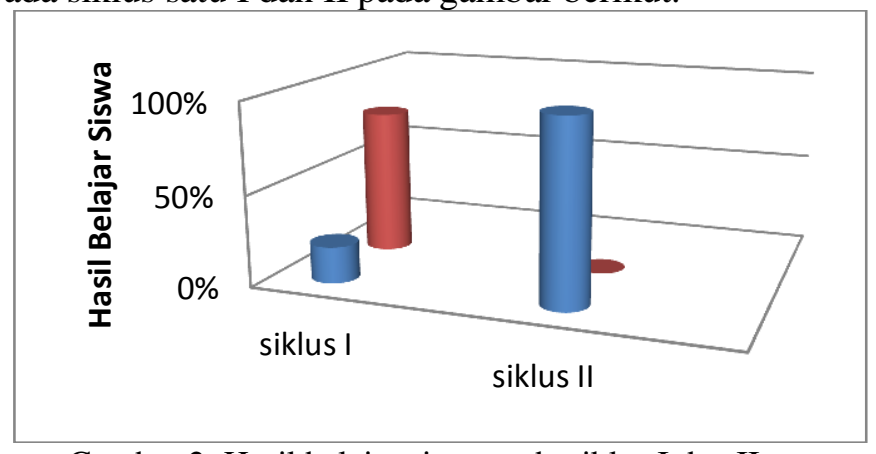

Gambar 2. Hasil belajar siswa pada siklus I dan II

Berdasarkan gambar di atas persentasi hasil belajar pada siswa yang diperoleh di siklus I yaitu sebesar $20 \%$ dengan nilai rata-rata 66,28 artinya dari 25 siswa kelas VIII yang mengikuti tes, terdapat 8 siswa yang tuntas, dikatakan tuntas karena hasil tes yang diperoleh siswa telah mencapai nilai KKM (Kiteria Ketuntasan Minimal). Sedangkan 17 siswa yang tidak tuntas dikarenakan hasil tes yang diperoleh belum mencapai KKM yang telah ditentukan. 
Persentasi hasil belajar siswa yang diperoleh pada siklus II yaitu sebesar 100\% dengan diperoleh nilai rata-rata sebesar 89,32 artinya dari 25 siswa kelas VIII yang mengikuti tes, terdapat 25 siswa yang tuntas. Siswa tersebut dikatakan tuntas karena hasil tes yang diperoleh pada siklus II telah mecapai KKM yang telah ditentukan. Dari data tersebut maka hasil dari siswa pada siklus II dikatakan terjadi peningkatan, sebesar $80 \%$.

\section{Aktivitas Guru Pada Siklus I dan II}

Berdasarkan data observasi terhadap aktivitas guru, dapat dilihat melalui gambar di bawah ini.

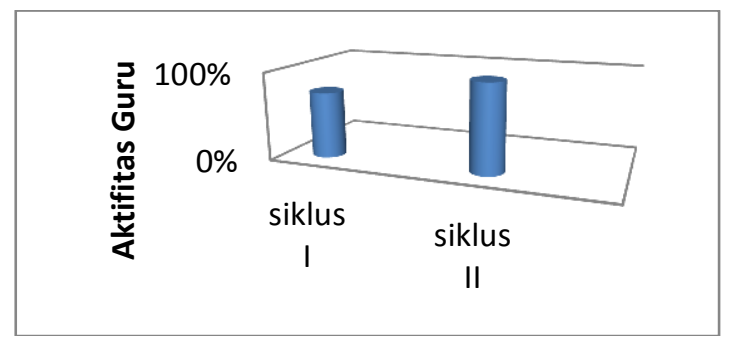

Gambar 3. Aktivitas guru pada siklus I dan II

Berdasarkan gambar di atas, diperoleh presentasi aktivitas guru pada siklus I yaitu $70 \%$ dalam siklus I yang diperoleh oleh guru masih dalam kategori cukup.

\section{Aktivitas Siswa Pada Siklus I dan II}

Data hasil observasi aktivitas siswa, dapat dilihat melalui gambar di bawah ini.

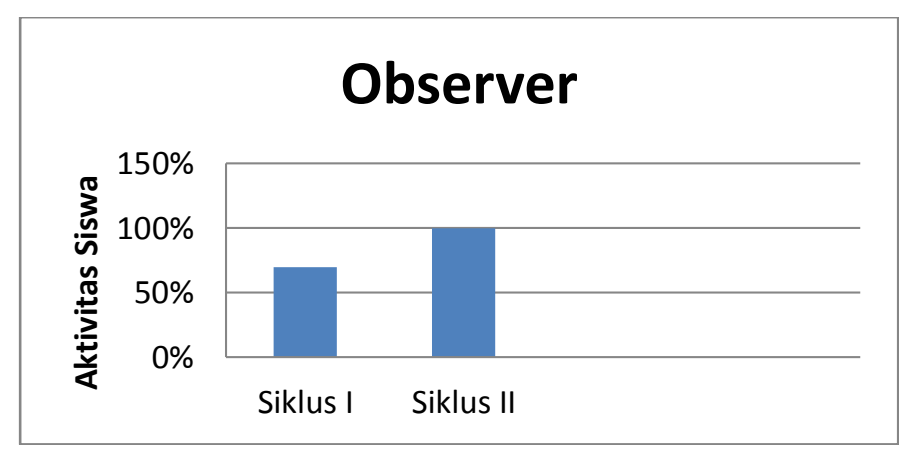

Gambar 4. Aktivitas Siswa pada siklus I dan II

Berdasarkan hasil observer pada gambar di atas, aktivitas siswa selama guru menerapkan model PBL dari hasil observasi aktivitas siswa oleh observer (Rumaisa Hamza. S.Pd.) menunjukkan peningkatan, yakni pada siklus I sebesar $70 \%$ meningkat menjadi $100 \%$ di siklus II.

\section{PEMBAHASAN}

\section{Hasil Belajar Siswa Siklus I Dan II}

Hasil belajar siswa pada siklus I diketahui bahwa 25 siswa yang mengikuti (test), yakni ada 8 siswa yang nilai tesnya sudah mencapai KKM (Kriteria Ketuntasan Minimal).yang telah di tetapkan 71. Dapat diketahui bahwa pada siklus I ketuntasan belajar hanya mencapai $20 \%$ dan sisanya $80 \%$ siswa tidak tuntas.

Kerja sama peserta didik pada siklus I cukup baik karena belum terbiasa dengan model pembelajaran yang dilaksanakan, masih banyak peserta didik yang pasif dalam kelompoknya. Pelaksanaan pembelajaran pada siklus I masih perlu diperbaiki, agar kemampuan dalam memecahkan masaalah dan kerja sama dapat ditumbuh kembangkan sehingga prestasi belajar dapat ditingkatkan. 
Pelaksanaan pembelajaran pada siklus II sudah lebih baik dari sebelumnya, motivasi yang diberikan oleh guru juga meningkatkan hasil belajar siswa pada siklus II. Diketahui bahwa dari 25 siswa yang mengikuti tes (post test), yakni terdapat 25 siswa 100\% tuntas dan telah mencapai KKM (Kriteria Ketuntasan Minimal).

Pada hasil test akhir siklus dapat dilihat jumlah siswa yang tuntas dan belum tuntas kemudian dibandingkan tiap siklus untuk mengetahui peningkatan hasil belajar. Tingkat ketuntasan hasil belajar pada siklus II mencapai $100 \%$. Berdasarkan data hasil belajar siswa pada siklus II terdapat banyak perubahan. Peneliti berasusmsi bahwa adanya peningkatan hasil belajar siswa pada siklus I ke Siklus II karena siswa yang sebelumnya tidak memahami materi yag diberikan oleh guru, sudah dipelajari oleh siswa dan memahaminya. Hal ini terlihat dari hasil tes yang cukup memuaskan pada saat guru memberikan test akhir. Menurut Slameto (2010) hasil belajar merupakan kemampuan yang dimiliki individu setelah proses belajar mengajar berlangsung, yang dapat memberikan perubahan tingkah laku baik pengetahuan, pemahaman, sikap dan keterampilan siswa sehingga menjadi lebih baik dari sebelumnya.

Penerapan pembelajaran melalui model PBL dapat mengantarkan siswa berperan aktif dalam mengikuti proses pembelajaran, karena guru juga membantu mengorentasikan siswa pada masaalah, mengorganisasikan siswa untuk belajar, membantu siswa penyelidikan mandiri dan kelompok, serta mengembangkan dan menyajikan artefak (hasil karya) dan proses pemecahan masaalah. Selain itu, siswa juga dapat belajar langsung dalam kelompok dengan adanya pembelajaran kelompok, siswa dapat belajar tuntas tentang kelemahan atau ketidak tahuan materi yang belum dipelajarinya. Oleh karena itu, ketuntasan belajar seorang siswa sangat mempengaruhi hasil belajar siswa.

Berdasarkan hasil observasi penerapan siklus belajar oleh guru dalam desain RPP dengan Model PBL, kemampuan pegelolaan pembelajaran oleh guru pada siklus I memperoleh Skor $70 \%$ yang termasuk dalam kategori cukup baik. Skor yang diperoleh guru pada siklus I ini, menunjukan bahwa guru masih kurang melaksanakan proses pembelajaran sesuai dengan isi rencana pembelajaran.

Berdasarkan hasil observasi pada siklus II dengan penerapan model pembelajaran Problem based learning oleh guru dalam desain RPP, kemampuan pembelajaran oleh guru pada siklus II memperoleh skor $100 \%$ yang termasuk dalam kategori baik sekali. Skor yang diperoleh oleh guru pada siklus II ini menunjukan bahwa guru telah melaksanakan proses pembelajaran dengan baik sesuai dengan isi rencana pelaksanaan pembelajaran sehingga aktivitas guru dari siklus I ke siklus II mengalami peningkatan.

\section{Aktivitas Siswa Siklus I dan II}

Aktivitas siswa selama proses pembelajaran berlangsung dengan menerapkan model Problem Based Learing, dari hasil observasi observer Rumaisa Hamza S.Pd (Guru) 70\% presentasi aktivitas siswa tersebut menunjukan bahwa siswa kurang aktif dalam proses pembelajaran. Menurut Prabawanti (2011) dalam Sahran (2013), keaktifan siswa dalam proses pembelajaran akan menyebabkan interaksi yang tiggi antara guru dengan siswa ataupun siswa dengan siswa itu sendiri. Siswa yang memiliki aktifitas belajar tinggi berarti mempunyai keinginan yang tinggi dalam belajar. Siswa akan terlihat lebih aktif dalam mengikuti pembelajaran. Sebaliknya, siswa yang memiliki aktifitas rendah akan terlihat pasif dalam mengikuti pelajaran.

Persentase aktivitas siswa pada siklus II mencapai $100 \%$ persentasi siswa tersebut menunjukan bahwa siswa sudah aktif dalam proses pembeajaran dan semua aspesk yang diamati oleh observer telah dilakukan oleh siswa. Hal ini didasarkan pada setiap aspek untuk presentasi aktifitas siswa telah memenuhi kreteria efektif. Menurut Ahmad (2004), dalam Sabir (2015), keberhasilan belajar peserta didik tidak semata-mata ditentukan oleh kemampuan yang dimilikinya, tetapi juga ditentukan oleh minat, perhatian dan motivasi belajarnya. Sering ditemukan peserta didik yang mempunyai kemampuan 
yang tinggi gagal dalam belajarnya disebabkan kurangnya minat,perhatian dan motivasi hakikatnya merupakan usaha peserta didik dalam mencapai kebutuhan belajarnya.

Selain motivasi, kompetensi guru juga mempengaruhi peningkatan aktivitas siswa, hal ini diperkuat oleh pendapat Soetjipto dan Kosasi (2002) dalam Khoni (2012) . menyatakan bahwa guru harus selalu dapat menyesuaikan kemampuan dan pengetahuannya degan keinginan dan permintaan masyarakat, dalam hal ini peserta dan para orang tuanya. Keinginan dan permintaan ini selalu berkembang sesuai dengan perkembangan masyarakat yang biasanya dipengaruhi oleh perkembangan ilmu dan teknologi. Oleh karena itu guru selalu dituntut untuk secara terus menerus meningkatkan dan mengembangkan pengetahuan, dan keterampilan jika kemampuan yang dimiliki seorang guru rendah akan mempengaruhi aktivitas siswa maupun hasil belajar siswa.

\section{KESIMPULAN}

Berdasarkan hasil penelitian yang peneliti lakukan di MTS Ar-ridha Pasimbaos Kabupaten HalmaheraSelatan dapat disimpulkan bahwa:

1. Dengan menerapkan model pembelajaran Problem Based Learning dapat meningkatkan hasil belajar siswa. Hal ini dapat dibuktikan dari hasil penelitian yang menunjukkan adanya peningkatan hasil belajar siswa siklus I 20\% dan siklus II 80\%, aktifitas siswa siklus I 70\% dan siklus II 100\%, dan aktifitas guru siklus I 70\% dan siklus II 100\% maka peningkatan dari siklus I ke siklus II sebesar $30 \%$.

2. Aktivitas belajar siswa yang diperoleh pada siklus I dalam mempelajari atau menerima telah mengalami peningkatan dari siklus I yaitu $20 \%$ meningkat menjadi $80 \%$. Sehingga pada siklus II dinyatakan baik.

3. Aktivitas guru yang diperoleh pada siklus I yaitu $70 \%$ dan pada siklus II telah mengalami peningkatan sebesar $30 \%$.

\section{DAFTAR PUSTAKA}

Depdiknas. 2003. Undang-Undang RI Nomor 20, Tahun 2003, tentang Sistem Pendidikan Nasional.

Gulo, W. 2002. Strategi Belajar Mengajar. Jakarta : Grasindo.

Khoni. 2012, Langkah Mudah Penelitian Tindakan Kelas Sebagai Pengembamgan Profesi Guru. Jakarta: PT Rajagrafindo Persada.

Rustam Hasim “ Peranan Guru Kelas Dalam Meningkatkan Minat Belajar Siswa Pada Mata Pelajaran PKN DI SD Negeri Tabam” Jurnal Pedagogic. PGSD Unkahir Ternate Vol 1 No 2 Juni 2013.

Rustam Hasim, “Peranan Kepala Sekolah Sebagai Supervisior Dalam Meningkatkan Kualitas pembelajaran, (telaah Teoritik)”. Jurnal Edukasi, Vol. 16 No. 2 Juni 2018.

“Kompetensi Guru Kelas Dalam Pembelajaran IPS Di Sekolah Dasar (TelaahTeoritik)”, Jurnal Pedagogic, PGSD Unkahir Ternate. Vol 1 No 4 Juni 2014.

Sabir. 2015. Pengelolaan Pembelajaran. Jakarta: Rineka Cipta.

Sahra. 2013. Proses belajar mengajar. Jakarta: Bumi Aksara.

Slameto. 2010. Belajar dan Faktor-faktor yang Mempengaruhinya. Jakarta: Rineka Cipta.

Suci. 2008. Penerapan Model Problem Based Learning Untuk Meningkatkan Partisipasi belajar dan Hasil Belajar Teori Akuntansi mahasiswa jurusan.

Suharsimi, A. Suhardjono. \& Supardi. 2008. Penelitian Tindakan Kelas. Jakarta: Bina Aksara.

Trianto. 2007. Model-model Pembelajaran Inovatif Berorientasi Konstruktivistik. Jakarta: Prestasi Pustaka.

Turyanto, R. 2007. Problem Based Learning, (Online), http://ragilt.org/archives/ case-problem-based-learning.html, diakses 10 september 2018.Malang: Universitas Negeri Malang. 